\title{
Workforce Reduction: \\ Strategic, Legal And Employee Concerns
}

Arthur K. Fischer, Pittsburg State University, USA

Mary Henderson, Pittsburg State University, USA

\begin{abstract}
This article is about an HRM case dealing with problems of a company faced with the need to reduce the costs of its workforce. Discussion concerns how such a case can be used to exhibit the alignment between HRM strategies, legal mandates and employee preferences.
\end{abstract}

Keywords: HRM Case; Separation; Workforce Reduction; HRM Strategy

\section{INTRODUCTION}

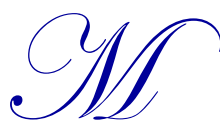

idwest Education, Inc. is a major supplier of educational materials for the United States. The company focus is on learning tools and systems for use in technology, science and business classrooms. In addition, it develops and provides books, manuals, videos, software and hardware used in the fields of technology education, instructional development and business applications.

The company has its headquarters and primary manufacturing plant in a major Midwest community. In addition, the Creative Development offices are located in Massachusetts and California. Transportation, Service and Maintenance facilities are headquartered out of Texas, with major branches in Baltimore and Phoenix.

The three main divisions exemplify three different strategies: cost-reduction, quality enhancement, and innovation (as discussed by Schuler and Jackson, 1987).

1. Transportation, Service and Maintenance. The primary strategy of the Transportation, Service and Maintenance Division is cost-reduction. Midwest Education, Inc. has long been known for providing service and maintenance programs which are very reasonably priced.

2. Manufacturing. The primary strategy of the Manufacturing Division is quality enhancement. Midwest education, Inc. has an enviable history of providing the highest quality products which have been adopted by first-rate schools and corporate training programs.

3. Creative Development. The primary strategy of the Creative Development Division is innovation. Midwest Education, Inc. is widely known for providing truly cutting edge teaching materials which always mirror the latest techniques and processes.

Various HRM problems occur at these different facilities which require students to develop responses and show how they can support the overall strategic plans of the division involved.

\section{COMPANY HISTORY}

Midwest Education was started by Henry and Mary Dalton in 1975. Dr. Henry Dalton was an industrial arts teacher before he got his MBA and went on to get his Ph.D. in Technology Education. Mary was a software developer who also taught business seminars. At that time, a new wave of emerging technology was beginning to alter the way people learn and communicate. By developing Midwest Education, Inc., the Daltons began work in an exciting new field. They found a vast market for quality tools that educated people on how to use all the new technology. Dr. and Mrs. Dalton are in semi-retirement now and travel extensively, but remain major shareholders in the business. They personally hired the CEO when they went into semi-retirement. 
The company started with about fifty employees but has grown consistently and now has a total of 416 employees within its three major divisions: 158 employees work in the Manufacturing Division, 123 employees work in the Creative Development Division, and 135 work in the Transportation, Service and Maintenance Division. There are also 71 employees working at the headquarters in Kansas City (including the corporate staff).

At the beginning on the 1990s, it became apparent that international business was becoming the rule rather than the exception. The company went international in 1994 and now is exporting to three European, two Latin American, and two Pacific Rim countries. The Global Operations Division is located within the headquarters.

\section{Headquarters}

The corporate headquarters are in Kansas City. The CEO of Midwest Education, Inc. is Judith Lund who was hired by the Daltons in 1994 when they decided to take a less active role in the company while remaining major shareholders. Ms. Lund has an MBA in business management and was previously the CEO of a small telecommunications company. In her previous position, Ms. Lund had successfully steered the company out of financial difficulties by raising stock value. She had initiated a strong advertising campaign and had put the company 'in the black' for the first time in seven years.

The COO of Midwest Education, Inc. is Frank Rose. Frank has been with the company since 1989. Mr. Rose, a cousin of Dr. Dalton, had a successful career with an international business training group in California. His desire to move back to his home town of Kansas City came at a time when the Daltons were looking for a COO. He has worked out well for the company.

The Human Resources Department is also located at the headquarters. The Vice President for Human Resources is Lawrence Wilson who has a degree in industrial and organizational psychology and an MBA and has been with the company for 11 years. He started out as a generalist and was promoted as he showed good judgment with hiring and earned his MBA at the same time.

Within the Human Resources Department there are four sections:

1. Staffing, headed by Patrick Shew.

2. Compensation and benefits section, headed by Michael Martin.

3. $\quad$ Labor management relations section, headed by Keith Lane.

4. Training, career development and performance appraisal section, headed by Cynthia Burns.

There are also human resource specialists in each of the three divisions around the country.

\section{Manufacturing Division}

The mission statement for the Manufacturing Division is: "The aim of the Manufacturing Division of Midwest Education, Inc. is to continually improve the quality and strength of all our products. The superior products for which we have become world renowned will still be manufactured along with new and innovative products and ideas. We will work hard to keep quality high and cost down while supplying customers with the best possible products in the shortest possible time." The Manufacturing Division follows a strategy of quality enhancement.

The main manufacturing plant is located on the outskirts of Kansas City, not far from the company headquarters. The president of the Manufacturing Division is Max Thorn who is one of the first employees hired by the Daltons. He started writing programs for the company and originally worked alongside the Daltons in interviewing and hiring many other employees.

The head of human resources for the Manufacturing Division is Janine Woods. She has a staff of five generalists who assist her in meeting HRM needs for the Manufacturing Division. 
The Manufacturing Division used to be housed in the same building as the headquarters. As the business expanded and more room was needed, the division moved to the suburbs into a large factory site. There are 158 employees who are divided into ten teams, each working at producing and packaging a specific product at one time. There are five supervisors who each supervise two teams: Doris Malone, John Fizer, Sandi Cross, Wendy Atchison, and Ian Carpenter.

The Manufacturing Division usually has a long lead time on orders and can anticipate what will be needed. The factory has flexible work areas that can be re-tooled and rearranged for the changeover from one product to another in less than four hours. The pay in this division starts at $\$ 6.25 / \mathrm{hr}$. for production workers and offers a full benefits package. Most employees seem happy with their work and Max Thorn is generally thought of as a good, easy-going man to work for.

\section{Creative Development Division}

The mission statement for the Creative Development Division is, "In the Creative Development Division of Midwest Education, Inc., we will strive to bring our customers the most innovative and cutting edge programs and products in the world. Our team of creative professionals is constantly working to improve, upgrade, and create the most useful products to bring to our customers." This division follows a strategy of innovation.

The Creative Development Division has two locations - a headquarters in California and a branch in Massachusetts. The president of the Creative Development Division is Serena Tibaldo who recently joined the company. She was previously a software developer for a large computer game producer. She has a bachelor's degree in business and a computer programming master's degree, and is doing very well at Midwest.

The head of human resources for the Creative Development Division is Amelia Chi, who is located at the California headquarters and has a staff of five assistants. The head of the human resource section at the Massachusetts branch is Virginia Fox who has a staff of two assistants.

There are 90 people employed at the California plant and 38 at the Massachusetts location. The California location opened in 1980 and the Massachusetts branch was opened in 1993. In the 1970's and 1980's, many computer software programmers moved to the west coast to be located in Silicon Valley. Most people hired by Midwest Education, Inc. transferred from wherever they lived to the California branch, with the company paying all relocation expenses. By 1990, some employees desired to live in the east. The Daltons decided it was time to expand the company and, in doing so, decided the next branch would be in the Massachusetts area. Most of the longtimers elected to remain in California while the majority of recent hires are in Massachusetts.

\section{Transportation, Service And Maintenance Division}

The mission statement for the Transportation, Service and Maintenance Division is, "The Transportation, Service, and Maintenance Division is committed to providing the fastest and most cost-effective way of safely shipping our product to our customers. No effort will be spared as we streamline and improve our fast and friendly service". The Transportation, Service and Maintenance Division follow a strategy of cost reduction.

The Transportation, Service and Maintenance Division headquarters is located in San Antonio, Texas and major branches are in Baltimore, Maryland and Phoenix, Arizona. The President of the Transportation, Service and Maintenance Division is Mark Derrick who is based in San Antonio and has been with Midwest Education, Inc. for 13 years. He personally hires the managers for the other branches in Maryland and Arizona.

The head of human resources for the Transportation, Service and Maintenance Division is Salvador Vasquez who has a staff of five assistants. Mr. Vasquez appoints HR heads to the other branches who are often employees from San Antonio and that he knows well and trusts.

The Transportation, Service and Maintenance Division was originally based in Kansas City. As the company grew, a decision was made to relocate the division to Texas. The other branches are newer, with Maryland 
opening in 1989 and Arizona in 1996. There are 55 employees in San Antonio and 40 in each of the other two branches.

\section{SITUATION}

As with most businesses, Midwest Education, Inc. has been struggling in the midst of the "great recession." Since the onset of the economic downturn in 2008, the company has gone through the process of "trimming the fat" to maintain operational efficiency. After numerous budget cuts and changing to more lean systems wherever possible, the company still needs to reduce its budgetary expenses. Although the company has done its best to avoid cuts that would negatively impact its employees, it seems that is no longer an option.

CEO Judith Lund and COO Frank Rose have called a meeting to discuss potential ways to reduce the company's salary expense. Additional meeting attendees included Lawrence Wilson - Human Resources VPHR, Patrick Shew - Staffing, Michael Martin - Compensation and Benefits, Keith Lane - Labor Management Relations, and Cynthia Burns - Training, Career Development and Performance Appraisal; from the Manufacturing Division, President Max Thorn and HR head Janine Woods; from the Creative Development Division, President Serena Tibaldo and HR head Amelia Chi; from the Transportation, Service and Maintenance Division, President Mark Derrick and HR head Salvador Vasquez.

Judith Lund - CEO: As you all know the company has been struggling financially for a few years now. Although we have all worked very hard to reduce costs across the board, it hasn't put us in the financial position we were hoping for. Unfortunately, we are going to have to reduce our salary budget.

Keith Lane - HR, Labor Management Relations: How bad is it? Is this something that we can manage with reduced work weeks or unpaid vacations?

Frank Rose - COO: Part of what we've found in our efforts to streamline operations is that we simply have too many people for our current strategy and future demand. Compound those findings with today's economic climate and the result is that we simply have to reduce our workforce.

Michael Martin - HR, Compensation and Benefits: We had a record number of employees attend our retirement planning session this year. An early retirement program would definitely be better received than layoffs. Our senior workers seem positive about their nearing retirements; it probably wouldn't take much to expedite their leaving. I really feel a small lump sum coupled with continued health benefits to age 66 would be enough incentive for many of our workers to go ahead and retire. The retirement plan for our hourly employees differs from that of our salaried employees, but I think both groups would be equally receptive if we should decide to offer it to both.

Max Thorn - Manufacturing Division: I say let go of the new employees; last hired-first fired. My department needs experience; I can't lose all my older more experienced workers.

Janine Woods - HR, Manufacturing Division: That would also be safest for the company, legally speaking. It would reduce the possibility of wrongful termination claims.

Serena Tibaldo - Creative Development Division: There is no way I'm firing all of my recent hires. Do you know how hard it is to find new creative talent? My two newest hires are potentially the most innovative people in the department. If we are going to compete in today's market, I'm going to have to have fresh ideas. I recommend we part ways with our least productive employees.

Cynthia Burns - HR, Training, Career Development and Performance Appraisal: That would be great for your department but not for everyone else's. Unfortunately, we still have supervisors that don't take full advantage of the performance appraisals, so terminations based purely on those supervisor's evaluations could create some legal pitfalls. 
Mark Derrick - Transportation, Service and Maintenance Division: Why don't we just cut the highest paid across the board? We could fire less people and save the most money that way. Firing anyone is going to be hard enough; the fewer the better.

Max Thorn: No thanks, I would lose my most experienced employees. Recouping the knowledge base would take years. If we lose that much experience all at once, it's guaranteed that production levels will go down and so will quality.

Serena Tibaldo: I agree. I would lose my most talented employees. In today's market, talent comes at a premium. If I lose my top earners, I lose my top talent. It will cost more money to replace them than to keep them.

Frank Rose: Again, this isn't just about money. We need to downsize in a way that strengthens the company strategically.

Serana Tibaldo: There's a new trend I've seen companies using in which they offer employees a lump sum payment to quit. It's an innovative way to weed out employees that aren't truly happy in the company. Unhappy workers are usually less productive and less motivated. I would much rather lose employees that don't want to be here than any who do.

Patrick Shrew - HR, Staffing: That's a really recent practice; I don't know a lot about it, but I have heard of it just within the last couple of years. You're right, it's always better to have voluntary separations rather than forced separations. However, without some kind of employee climate survey, we may find ourselves losing more people than we can afford. We would be paying people to leave and at the same time spending more money in recruiting, selection and training. I would really want to look at some models and learn more about it before seriously considering it as an option.

Lawrence Wilson - VPHR: There are multiple ways we can go about reducing our salary costs, but we are going to have to be very careful to protect both our employees and the company. With morale and productivity already low, we need to proceed cautiously. This is going to be hard on everyone, but it will be easier if we can all get on the same page and enact a clear direct plan.

That being said, with our current staffing situation, I don't think this is going to be as simple as deciding on one simple, company-wide separation criterion. With a company this diverse and with as many cuts as we need to make, we are probably going to have to implement, at minimum, a two-tier plan. Further, we may even need to have a specialized plan for each division.

Mark Derrick: Maybe this is obvious to everyone else, but I have to ask - what exactly do you mean by two-tier?

Lawrence Wilson: Any one separation criterion alone is likely not going to get us where we are trying to go. So, we will have to choose our most favorable criterion for our tier 1 or first round cuts, reevaluate our position, and then use our second most favorable criterion for any tier 2 or remaining cut. Patrick, you have more experience with this; am I off-base here?

Patrick Shrew: Not at all Wilson. This is exactly how we did things at my previous company after our merger. Our first step was to implement a company-wide early retirement incentive program. When the open window for that program closed, we determined how many more cuts needed to be made in each division. HR worked with the division heads to determine the best way to make cuts within those divisions, given their strategy. In fact, in some divisions, they had to implement a three-tier plan to make the numbers.

Lawrence Wilson: Thanks, Patrick. I would like each division president to work with your division's HR department and submit a staffing reduction proposal to me. Outline the major concerns and goals for your department as they pertain to the proposal. Remember that while we would love to make these cuts on a purely voluntary basis, we have to factor in what's best for productivity and the overall success of the company as well. 


\section{QUESTIONS \& ACTIVITIES}

1. Create a two-tier separation plan for each of the three company divisions that will support the division's strategy. Example:

Division: Name of Division

- $\quad$ Tier 1 - type of separation (i.e., early retirement; last hired - first fired; etc.)

$\circ \quad$ How does this support the division strategy?

- $\quad$ Tier 2 - type of separation

$\circ \quad$ How does this support the division strategy?

*Note - Tier 1 separations are those you would make first. Tier 2 separations are those you would make if more were required.

2. Create a two-tier separation plan that could be used across the company.

3. Should Midwest Education, Inc. use a different plan for each division or a company-wide strategy? Why?

4. What are some additional steps the company may want to take to ensure the downsizing goes smoothly and that morale doesn't plummet (e.g. implementation issues)?

\section{AUTHOR INFORMATION}

Dr. Art Fischer is a Professor of Management in the Department of Management and Marketing at Pittsburg State University. He is a FELLOW with the American College of Healthcare Executives and is a retired healthcare executive. E-mail: afischer@ pittstate.edu (corresponding author)

Mary Henderson is a graduate student at Pittsburg State University. E-mail: maryhen@gmail.com

\section{REFERENCES}

Schuler, R. S., \& Jackson, S. E. (1987). "Linking competitive Strategy with Human Resources Management Practices", Academy of Management Executives, 1 (August, 1987), p.213. 


\section{INSTRUCTOR'S NOTES}

Question 1: There isn't one right answer, but students should focus on the strategy of each division in creating their plans. The plan for the Creative Development Division should support innovation; the plan for the Manufacturing Division should support quality; and the plan for the Transportation, Service and Maintenance Division should support cost reduction. Students should be creative - encourage students to utilize various separation techniques, such as attrition, early retirement, and so forth.

Question 2: The plan should take into account the strategies of all the divisions and the overall success of the company. The plan should not completely undermine the strategy of any one division.

Question 3: Students should recognize that allowing each division to enact its own plan will help to ensure that each separation will support the overall strategy of that division. Further, it will reduce the negative impact of the separation on the remaining employees and the division. Students should also recognize that one plan for all three divisions can help reduce confusion, resentment, legal concerns and overall loss of morale. This would seem to be more equitable for all Midwest Education employees (i.e., we would not have some employees feeling that others are more privileged than they are).

Question 4: Students should address things such as notifying employees of the impending separations, communicating to laid-off employees, coordinating media relations, maintaining safety and security of the company and surviving employees, reassuring the survivors of the layoff, and perhaps coordinating outplacement services. 


\section{NOTES}

